\title{
An Epidemiological Study of Snake Bite Cases in Children of Nepal
}

\author{
Joshi DD1 \\ ${ }^{1}$ Dr. Durga Datt Joshi, MPVM, FISCD, WHO Expert Panel Member on Zoonoses, Executive Chairman, National \\ Zoonoses and Food Hygiene Research Centre (NZFHRC) GPO Box: 1885 Chagal, Kathmandu, Nepal. Jeevan Smriti \\ Marg House no. 468 Ward no. 13, KMC Phone: +977-1-4270667, +977-1-4272694.
}

Address for Correspondence: Dr. Durga Datt Joshi, E-mail: ddjoshi@healthnet.org.np

\begin{abstract}
Introduction: Snakebite is common in the Terai region of Nepal. Injury and mortality of humans due to Snake envenomation is a serious pubic health problem in Southeast Asia and Nepal. It has been thought that at least 50,000 people in the region die of snake bites (this includes India, Bangladesh and Nepal and Pakistan) per year. There are abundant venomous snakes present in the region. Studies in Nepal have identified 4 species of snake responsible for the majority of fatal bites. These are the Indian cobra (Naja naja), common krait (Bungaris caeruleus) Russell's viper (Viper ressellii) and greenpit viper. The incidence of snakebite varies from 300-500 bites per 100,000 human populations in forested regions to 50-100 bites per 100,000 in Sahara. Objective: To study the epidemiology of snakebite in the endemic regions of the terai, to analyse the morbidity and mortality data of snakebite cases in children for the year 2008. Method: National Zoonoses and Food Hygiene Research Centre (NZFHRC) started collection of secondary and primary information on snakebite cases in children recorded and reported by different media and hospitals, health post in Nepal during the year 2008. The data had been compiled, tabulated and analysed. This is the regular surveillance study carried out on snakes in general and venomous snakebite human cases recorded in Nepal. The team visited in 6 mid, hill districts and 24 terai districts of Nepal. Results: Total snakebite cases in children were 540 during the year 2008. Of which 10 cases were from six mid hill districts and 530 were from 24 terai and inner terai districts of Nepal. Total morbidity was $406(75.19 \%)$ and mortality $134(24.81 \%)$. Seasonal incidence of snakebite cases recorded in Bheri zonal hospital and medical college Banke district. Highest morbidity were recorded during the month of Jestha (May) to Aswin (August). Morbidity 12 (25\%) and mortality 3 (20\%) were recorded in the month of May/June 2008. Conclusions: Snakebite cases in children and deaths were recorded and reported along with adult cases of snakebite. Total adult cases were 2190 of which children were $540(24.66 \%)$ during the year 2008. This means that about $25 \%$ of all cases of snakebites were seen in children every year in the endemic areas of snakes. Mass awareness school education programme about snakebite especially in endemic area of terai and inner districts should be advocated regularly so that parents along with children will take necessary precautions.
\end{abstract}

Key words: Snakebite, Epidemiological surveillance, Anti-snake venom, Poisonous and envenomation.

\section{Introduction}

E or the first time in the history of Nepal a baseline epidemiological study on snakebite treatment and management was conducted in 12 districts (Terai) of Nepal by the Zoonotic Disease Control Section of the Department of Health Services during the year 1984/85. People aged 10 to 40 years and particularly of male sex were more affected with a mortality rate of $5.6 \%$ annually ${ }^{1}$.

In collaboration with WHO a baseline epidemiology study was conducted from 1980 to 1985 in fifteen district hospitals and 3189 snakebite cases were treated of 
which 144 died with Case Fatality Rate (CFR) of $4.5 .^{2}$ Snakebite cases are observed mostly during summer and rainy seasons and males with ages ranging from 11 years to 50 years are mostly affected. This was studied in Nepal from east to west terai region of which most poisonous cases were recorded during the period from April to September. About $60 \%$ cases are bitten by venomous snake. The mortality is $27 \%$. However the maximum recorded snakebites cases are in June, July and August and that is the time when maximum agricultural field activities are being carried out. This has also been found also in India and other South East Asia countries. In Nepal polyvalent anti-snake venom serum (ASVS) produced by Halffkine Pharmaceutical Company, Bombay, India has been used in different hospitals ${ }^{3,4}$.

Different studies $^{5}$ in Nepal suggested that the Indian cobra and common krait are the problem snakes in the Terai region, while Russell's viper and the green pit viper (Trimeresurus albolabris) constitute a threat in the hill and mountain forest areas of Nepal.

Fear and dislike of snakes often leads to indiscriminate killing of snakes on sight, even though the great majority of snakes are non-venomous. In addition to the ecological impact of decimating snake populations, there are economic impacts to farmers of such actions. It has been suggested that $20-50 \%$ of Nepal's food grain crop is being destroyed by rodents.

Nationwide case fatality rate of snakebite was studied $^{6}$. The average Case Fatality Rate (CFR) is $8 \%$ and total cases bitten were 1917 and death 151. CFR is also calculated for hospital wise during different hospitals are not recorded and not available properly.

Objective: To study the epidemiology of snakebite in the endemic regions of the terai and to analyse the morbidity and mortality data of snakebite cases in children for the year 2008 .

\section{Materials and Methods}

National Zoonoses and Food Hygiene Research Centre (NZFHRC) started collection of secondary and primary information on snakebite cases in children recorded and reported by different media and hospitals, health post in Nepal during the year 2008. The data had been compiled, tabulated and analysed. This is the regular surveillance study carried out on snakes in general and venomous snakebite human cases recorded in Nepal. The team visited six mid, hill districts and 24 terai districts of Nepal.
The followings methodology was applied during the survey by the study team:

1. Collection of information on environment and snakes.

2. Collection and identification of snakes.

3. Epidemiological aspects of human snakebite.

4. Collection of morbidity and mortality record of human snakebite cases.

5. Observation of symptoms of snakebite cases.

6. Observation of snakebite case management and treatment.

7. Data compilation, tabulation and analysis.

8. Finally report writing.

\section{Results}

Snake bite cases in children, recorded in mid-hill district of Nepal during the year 2008

Snake Bite cases recorded in mid-hill district of Nepal during the Year 2008 from the media publication and NZFHRC survey team is presented in Table 1 and Figure 1. The total children (1-15 year) snakebite cases were 10 of which mortality $7(70 \%)$ and morbidity 3 (30\%). The most affected districts were Palpa, Syangja, Lamjung, Dailekha and Taplejung respectively during the year 2008

Month wise total snake bite cases in children reported and recorded in Bheri zonal and medical college teaching hospital in Banke by Media publication and NZFHRC survey team in five Development Regions of Nepal for the Year 2008 is presented in Table 2 and Fig. 2. Most children bitten by snakes through out the year were in the month of Baisakha $(n=5)$, Jestha $(n=12)$, Ashad $(n=11)$, Srawan $(n=8)$ and Bhadra $(n=6)$.

Snakebite cases in children and deaths reported and recorded in Terai and Inner Terai districts of Nepal during the year 2008 is presented in Table 3 and Fig 3. The total snakebite cases in children were 530 of which most of the affected districts are Rupandehi $(n=82)$, Banke ( $n=62)$, Saptari (62), Morang $(n=43)$, Nawalparasi $(n=32)$ and Sindhuli $(n=26)$.

Jestha to Bhadra months were the main season for snakebite cases, although snakes could be seen in all 12 months of the year. There are 3575 types of species and sub-species of poisonous and non-poisonous snakes found in the world, of which 77 types of species of poisonous and semi poisonous snakes are found in Nepal out of which about 21 types of species are 
poisonous and semi poisonous snakes are present in all terai districts of Nepal. There is always a threat of snakes in terai districts during summer and rainy seasons of the year. Generally cobra (Goman), King Cobra (Rajgoman), Krait, Munga, Russel-viper, pit viper (green pit viper and brown colour pit viper and yellowish green pit viper) are in the list of poisonous snakes in Nepal. About 100-150 people die due to snakebite annually reported here in Nepal. In India and Sri Lanka 3000 and 1000 people die annually respectively.

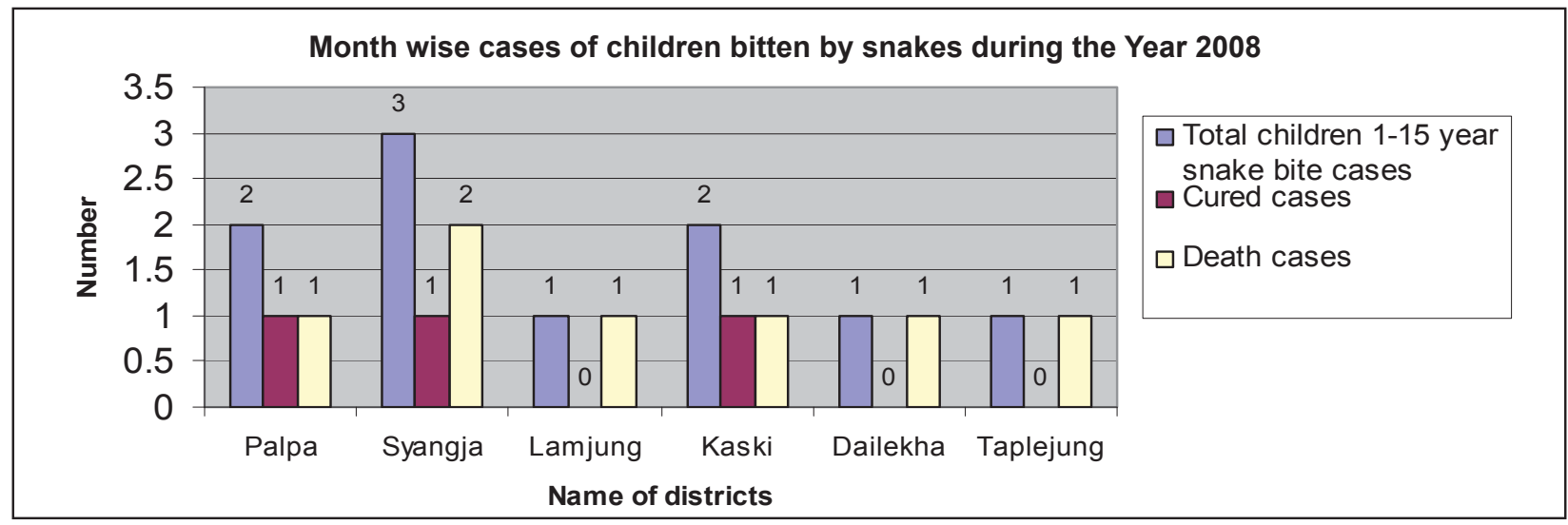

Fig 1: Cases of snakebite in children and deaths reported and recorded in mid hill districts of Nepal during the year 2008.

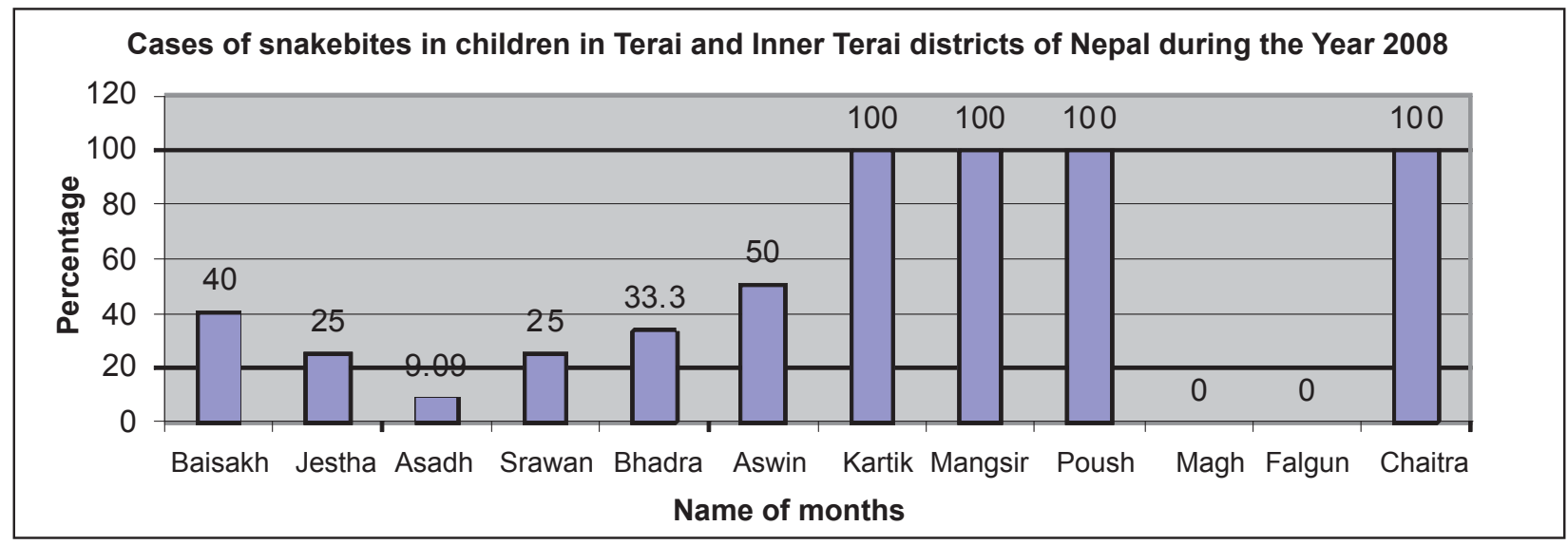

Fig 2: Month wise total children bitten by snakes reported and recorded in Bheri Zonal and Medical College Teaching Hospital in Banke District in 2008

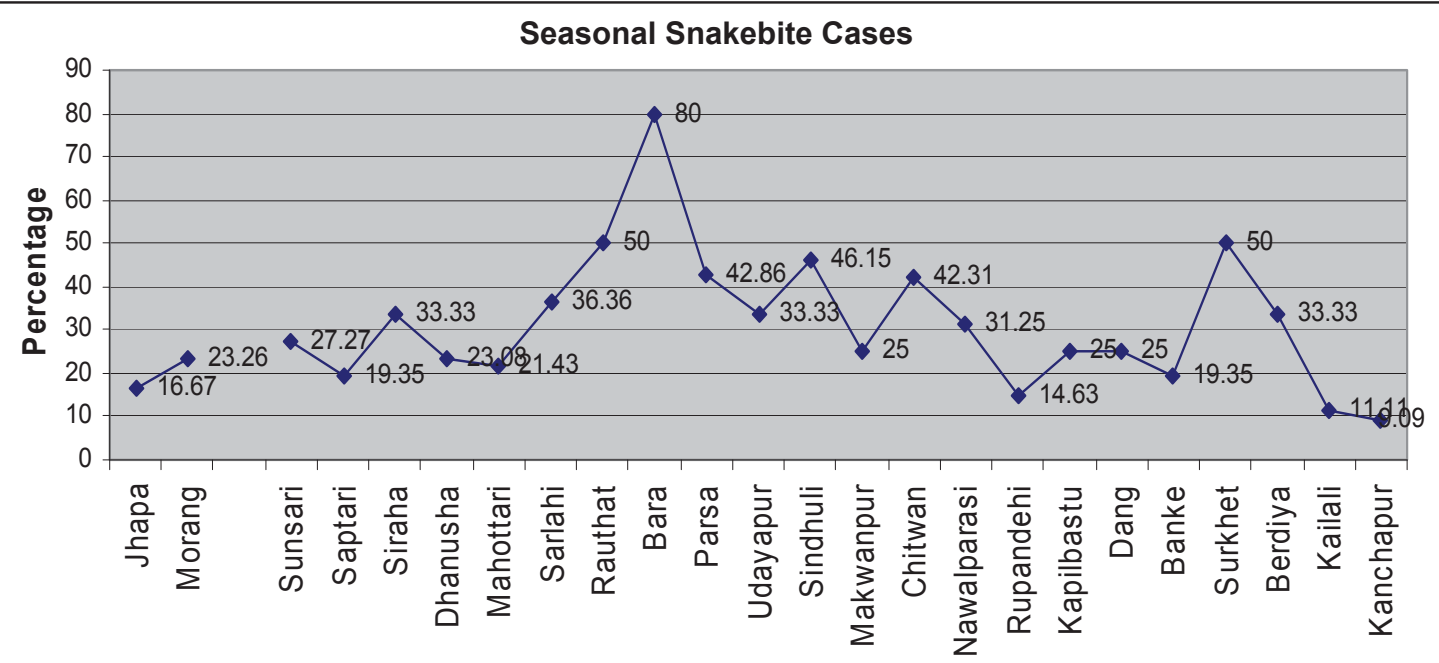

Name of Districts

Fig 3: Snakebite cases in children and deaths reported and recorded in Terai and Inner Terai districts of Nepal during the year 2008 
Table 1: Showing snakebite cases in children and deaths reported and recorded in mid hill districts of Nepal during the year 2008

\begin{tabular}{|c|l|c|c|c|c|c|}
\hline S.N. & District & $\begin{array}{c}\text { Total Adult and } \\
\text { children }\end{array}$ & $\begin{array}{c}\text { Total children 1-15 } \\
\text { years age group }\end{array}$ & Cured & Death & Percentage \\
\hline 1. & Palpa & 52 & 2 & 1 & 1 & 50.0 \\
\hline 2. & Syangja & 25 & 3 & 1 & 2 & 66.67 \\
\hline 3. & Lamjung & 11 & 1 & 0 & 1 & 100.0 \\
\hline 4. & Kaski & 10 & 2 & 1 & 1 & 50.0 \\
\hline 5. & Dailekha & 6 & 1 & 0 & 1 & 100.0 \\
\hline 6. & Taplejung & 1 & 1 & 0 & 1 & 100.0 \\
\hline \multicolumn{2}{r}{ Total } & $\mathbf{1 0 5}$ & $\mathbf{1 0}$ & $\mathbf{3}$ & $\mathbf{7}$ & $\mathbf{7 0 . 0}$ \\
\hline
\end{tabular}

Table 2: Month wise total children bitten by snakes reported and recorded in Bheri Zonal and Medical College Teaching Hospital in Banke District in 2008

\begin{tabular}{|c|l|c|c|c|c|c|}
\hline S.N. & Months & $\begin{array}{c}\text { Total Adult and } \\
\text { Children }\end{array}$ & $\begin{array}{c}\text { Total Children 1-15 } \\
\text { years age group }\end{array}$ & Cured & Death & Percentage \\
\hline 1. & Baisakh & 14 & 5 & 3 & 2 & 40.0 \\
\hline 2. & Jestha & 36 & 12 & 9 & 3 & 25.0 \\
\hline 3. & Asadh & 54 & 11 & 10 & 1 & 9.09 \\
\hline 4. & Srawan & 29 & 8 & 6 & 2 & 25.0 \\
\hline 5. & Bhadra & 12 & 6 & 4 & 2 & 33.3 \\
\hline 6. & Aswin & 13 & 2 & 1 & 1 & 50.0 \\
\hline 7. & Kartik & 5 & 1 & 0 & 1 & 100.0 \\
\hline 8. & Mangsir & 1 & 1 & 0 & 1 & 100.0 \\
\hline 9. & Pous & 1 & 1 & 0 & 1 & 100.0 \\
\hline 10. & Magh & 0 & 0 & 0 & 0 & 0.0 \\
\hline 11. & Falgun & 0 & 0 & 0 & 0 & 0.0 \\
\hline 12. & Chaitra & 2 & 1 & 0 & 1 & 100.0 \\
\hline & Total & 167 & 48 & 33 & 15 & 31.25 \\
\hline
\end{tabular}

Table 3: Snakebite cases in children and deaths reported and recorded in Terai and Inner Terai districts of Nepal during the year 2008

\begin{tabular}{|c|c|c|c|c|c|c|}
\hline S.N. & District & $\begin{array}{c}\text { Total Adult and } \\
\text { children }\end{array}$ & $\begin{array}{l}\text { Total children 1-15 } \\
\text { years age group }\end{array}$ & Cured & Death & Percentage \\
\hline 1. & Jhapa & 82 & 12 & 10 & 2 & 16.67 \\
\hline 2. & Morang & 163 & 43 & 33 & 10 & 23.26 \\
\hline 3. & Sunsari & 24 & 11 & 8 & 3 & 27.27 \\
\hline 4. & Saptari & 204 & 62 & 50 & 12 & 19.35 \\
\hline 5. & Siraha & 52 & 18 & 12 & 6 & 33.33 \\
\hline 6. & Dhanusha & 36 & 13 & 10 & 3 & 23.08 \\
\hline 7. & Mahottari & 44 & 14 & 11 & 3 & 21.43 \\
\hline 8. & Sarlahi & 82 & 11 & 7 & 4 & 36.36 \\
\hline 9. & Rauthat & 14 & 4 & 2 & 2 & 50.0 \\
\hline 10. & Bara & 36 & 5 & 1 & 4 & 80.0 \\
\hline 11. & Parsa & 66 & 7 & 4 & 3 & 42.86 \\
\hline 12. & Udayapur & 17 & 6 & 4 & 2 & 33.33 \\
\hline 13. & Sindhuli & 130 & 26 & 14 & 12 & 46.15 \\
\hline 14. & Makwanpur & 18 & 4 & 3 & 1 & 25.0 \\
\hline 15. & Chitwan & 111 & 41 & 30 & 11 & 42.31 \\
\hline 16. & Nawalparasi & 158 & 32 & 22 & 10 & 31.25 \\
\hline 17. & Rupandehi & 186 & 82 & 70 & 12 & 14.63 \\
\hline
\end{tabular}




\begin{tabular}{|c|l|c|c|c|c|c|}
\hline 18. & Kapilbastu & 102 & 16 & 12 & 4 & 25.0 \\
\hline 19. & Dang & 24 & 4 & 3 & 1 & 25.0 \\
\hline 20. & Banke & 167 & 62 & 50 & 12 & 19.35 \\
\hline 21. & Surkhet & 32 & 2 & 1 & 1 & 50.0 \\
\hline 22. & Berdiya & 70 & 15 & 10 & 5 & 33.33 \\
\hline 23. & Kailali & 136 & 18 & 16 & 2 & 11.11 \\
\hline 24. & Kanchanpur & 86 & 22 & 20 & 2 & 9.09 \\
\hline \multicolumn{2}{|l|}{ Total } & $\mathbf{2 0 4 0}$ & $\mathbf{5 3 0}$ & $\mathbf{4 0 3}$ & $\mathbf{1 2 7}$ & $\mathbf{2 3 . 9 6}$ \\
\hline
\end{tabular}

\section{Discussion}

Snakebite is a medical and public health problem in $\mathrm{Nepal}^{7}$. There are approximately over twenty thousand people bitten by snakes each year leading to death in less than 200 cases $^{8}$. The reported number of snakebite cases are usually under estimated. Over $70 \%$ of victims of snakebites need only careful observations and symptomatic treatment and not requiring antivenom treatment. During the survey of snakebite cases in Terai area of Nepal, it has been observed that there are too many non-venomous snakebite patients visiting hospitals $^{9}$. As an example, in Bharatpur hospital, the number of patients who visit emergency ward is eight times of that treated as venomous snakebite $\operatorname{cases}^{10}$. Because the medical doctors in the hospital knew about snakebite cases, the patients visiting hospitals were placed under observation. If systemic symptoms occured, treatment for envenomation, including antivenom therapy started ${ }^{11}$. When no symptoms occured several hours after arrival, the patients returned to their home without treatment ${ }^{12,13}$. Similarly, many nonvenomous snakebite patients visit hospitals or traditional healers. When people find snakes, they tend to kill the snakes only due to fear ${ }^{14,15,16}$.

There are numbers of paper written on snakebite by different authors who have suggested different guidelines for the treatment and snakebite management of the patients ${ }^{17,18}$.

Guideline for the management of snakebite for physicians in Nepal was prepared by NZFHRC which ables to answer and manage the following questions: 1) Is it a poisonous snake? 2) Are there any signs of systemic envenoming? 3) Which is the choice of antivenom and dosage? Finally, 4) How to treat the bitten wound and its complications? All these questions have to be answered and the patients properly treated.

\section{Conclusion}

Snakebite cases in children and deaths were recorded and reported along with adult cases of snakebite. Total adult cases were 2190 of which children were $540(24.66 \%)$ during the year 2008. This meant that about $25 \%$ of the total snake bite cases constituted children in the endemic regions of snakes. Mass awareness and school education programme about snakes and snakebite, especially in endemic area of terai and inner districts should be advocated regularly so that parents along with children can take necessary precautions.

\section{Acknowledgement}

I am most grateful to the reporting and recording media staff of Kantipur, Kathmandu Post, The Rising Nepal and Gorkhapatra, Himal, Nepal weekly news paper and other news paper published in Nepal. I must thank to all staff of NZFHRC particularly Ms. Meena Dahal for her work in data collection tabulation, analysis and interpretation.

\section{Funding: None \\ Conflict of Interest: None}

\section{References}

1. Joshi, D. D., Kawamura, Y., Toriba, M., Hayashi, Y. Epidemiological Surveillance Study of Snakes and Snakebite Human Cases in All Terai Districts of Nepal. NZFHRC, Chagal, Kathmandu, Nepal. 2007;1-52.

2. WHO. Zoonotic Disease Control: Baseline Epidemiology Study on Snakebite, Treatment and Management in Nepal. WHO weekly epidemiology. Rev.; 1987;42:319-20.

3. Pandey, DP. Epidemiology of Snake Bites Based on Hospital Survey in Chitwan and Nawalparasi Districts, Nepal. J Nep Health Research Council 2006;4:51-57.

4. Hansdak, SG, Lallar, KS., Pokharel, P., Shyangwa, P., Karki P., Koirala SA. Clinico-epidemiological study of snakebite in Nepal. Trop. Doctr, 2004;34(1):20-2. 
5. Joshi, D. D., Toriba, M., Kawamura, Y., Hayashi, Y. and Hawai Y. Snakes and Human Snakebite Cases in Chitwan District of Nepal, NZFHRC, Chagal, Kathmandu, Nepal. 1996;1-60.

6. Joshi, D. D. 2007. Snakebite Cases Recorded in Nepal, during the year 2004-2007. NZFHRC, Chagal, Kathmandu, Nepal. 2007;1-93.

7. Shah, K. B., Shrestha, J. M., and Thapa C. L. Snakebite Management Guideline. Department of Health Services Epidemiology and Disease Control Division Zoonoses Control Sub-Section. 2003;153.

8. Warrel, David A. Management of Snakebite review of the present status. Inter-country Consultative Meeting on Snakebite Management. WHO/SEARO New Delhi, 12-14, November 1981.

9. Warrel. David A. The global problem of snake bite: Its prevention and treatment. In: Gopalakrishnakone, P. \& Tan, C.K. eds, Recent Advances in Toxinology Research, Singapore, Venom \& Toxin Research Group, National University of Singapore, 1992;1:121153.

10. Warrel, David A. Clinical Features of Envenoming from Snakebite, Centre for Tropical Medicine, University of Oxford, United Kingdom. 1996

11. Warrel, David A. Clinical Manifestations and Treatment of Snakebite, Centre for Tropical Medicine, University of Oxford, UK. 1998
12. Dart Richard C, Horowitz Rivka and Gomez Hernan. Management of Poisonous Snakebite in the United States, Rocky Mountain Poison and Drug Center, University of Colorado, Denver, Colorado, USA. 1998

13. Russell F.E. Snake Venom Poisoning in the United States of America, College of Pharmacy, The University of Arizona, Tucson, AZ 85721, United States. 1996

14. White J. Treatment of Snakebite in Australia, State Toxinology Services, Women's and Childrens Hospital, North Adelaide 5A 5006, Australia. 1996

15. Joshi D.D. (1982) Epidemiological surveillance on snakebite case, treatment and mortality in Nepal. $J$ Nep Med Assoc 1982;20:22-30.

16. Joshi, D. D. (1983) An epidemiological survey of snakebite cases in Dhanusha District, J Nep Med Assoc 1983;21: 1-11.

17. Navy Bureau of Medicine and Surgery. Poisonous Snakes of the World, Chapter - V - Medical Treatment, Chapter VII-Distribution and Identification of Poisonous Land Snakes, US Government Printing Office, Washington, DC, USA. 1965

18. Sawai, Y (1993) Clinical Problem of Snakebites in South East Asia. Toxin-Related Diseases, Ed. A. T. Tu, Oxford and IBH Publishing Co. Ltd. New Delhi, India, 1993;445-469.

\section{How to cite this article ?}

Joshi DD. An Epidemiological Study of Snake Bite Cases in Children of Nepal. J Nep Paedtr Soc 2010;30(3):135-140. 